\title{
PENGARUH KINERJA PEGAWAI TERHADAP PENYELENGGARAAN DIKLAT DI PUSAT PELATIHAN MANAJEMEN DAN KEPEMIMPINAN PERTANIAN (PPMKP) CIAWI BOGOR
}

\author{
THE IMPACT OF EMPLOYEE'S PERFORMANCE AGAINST THE TRAINING \\ ADMINISTRATION HELD BY THE MANAGEMENT AND LEADERSHIP TRAINING \\ CENTER FOR AGRICULTURE (PPMKP) CIAWI BOGOR
}

\author{
Herdiansyah A.P1, Nandang S. Zenju ${ }^{2}$, Irma Purnamasari ${ }^{3}$ \\ 1Jurusan Ilmu Administrasi Negara Fakultas Ilmu Sosial dan Ilmu Politik Universitas \\ Djuanda, Jl. Tol Ciawi No. 1 Kotak Pos 35 Bogor 16770 \\ 2Jurusan Ilmu Administrasi Negara Fakultas Ilmu Sosial dan Ilmu Politik Universitas \\ Djuanda, Jl. Tol Ciawi No. 1 Kotak Pos 35 Bogor 16770 \\ 3Jurusan Ilmu Administrasi Negara Fakultas Ilmu Sosial dan Ilmu Politik Universitas \\ Djuanda, Jl. Tol Ciawi No. 1 Kotak Pos 35 Bogor 16770 \\ aKorespondensi: Feranny Juliefte
}

(Diterima oleh Dewan Redaksi: 01-02-2016)

(Dipublikasikan oleh Dewan Redaksi: 01-04-2016)

\begin{abstract}
This research is focused on the impact of employee's performace against the training administration held by The Management and Leadership Training Center for Agriculture (PPMKP) Ciawi, Bogor, because based on the observation on the field, employee's performance and training implementation are not yet optimized. The purposes of this study are: (1) To know the employees of PPMKP's performance, (2) To know how the PPMKP administered the training, (3) To assess if there is any impact on employee's performance against the training held by PPMKP. The type of research used is quantitative research with associative and descriptive methods. Purposive Sampling is the technique used involving 68 PPMKP employees as sample. The data gathering used was the study of literature and the study of field. To find out the employee's performances and training administration, analyses descriptive is applied with the result of 4,37 for performance which is in very good category with the lowest value is derived from the indicator expertise in completing the task. Whereas administration of training's result score of 4,39 which is in very good categoty with the lowest score is derived from the curriculum indicator. To determine the impact on the employee's performance of training administration the spearman rank correlation is used, with a correlation coefficient of 0,037 and a significance value of 0,766 with positive direction and not significant, meaning thet there is a very low impact on the performance by having training. The conclusion of the research shows that, (1) employee's performance has been very good with the lowest score is in in the indicator of realibility in completing task, (2) training administration has been very good with the lowest score is in the indicator of curriculum, also (3) there is very low impact on employee's performance against the trining administration. The possible suggestions made are: first, the expertise of emloyees in completing the task enhanced by giving trainings and study permits for their employees; second, curriculum plan is expected to be more adjustable with the participants by learning more on the participants background; third, research is carried out on other factors that influence the training administration, in order to see the effect on the level of training.
\end{abstract}

Key words: performance, training administration. 


\begin{abstract}
ABSTRAK
Penelitian ini memusatkan perhatian pada pengaruh kinerja pegawai terhadap penyelenggaraan diklat di Pusat Pelatihan Manajemen dan Kepemimpinan Pertanian (PPMKP) Ciawi Bogor karena dilihat dilapangan kinerja pegawai dan penyelenggaraan diklat yang masih belum maksimal. Penelitian ini bertujuan: (1) Untuk mengetahui bagaimana kinerja pegawai PPMKP, (2) Untuk mengetahui bagaimana penyelenggaraan diklat yang dilaksanakan oleh PPMKP, (3) Untuk menguji ada tidaknya pengaruh kinerja pegawai terhadap penyelenggaraan diklat di PPMKP. Jenis penelitian yang digunakan adalah peneletian kuantitatif dengan metode asosiatif dan deskriptif. Menggunakan teknik sampling yaitu Purposive Sampling dengan jumlah sampel 68 orang dari seluruh jumlah pegawai PPMKP. Teknik pengumpulan data di lakukan dengan cara studi kepustakaan dan studi lapangan. Untuk mengetahui bagaimana kinerja pegawai dan penyelenggaraan diklat, digunakan deskriptif analisis dengan hasil kinerja mendapat skor 4,37 yang berada pada kategori sangat baik dengan nilai terendah berasal dari indicator keahlian dalam menyelesaikan tugas, dan penyelenggaraan diklat dengan skor 4,39 yang berada pada kategori sangat baik dengan nilai terendah berasal dari indicator kurikulum. Untuk mengetahui pengaruh kinerja pegawai terhadap penyelenggaraan diklat menggunakan korelasi rank spearman, dengan nilai koefisien korelasi sebesar 0,037 dan nilai signifikansi sebesar 0,766 dengan arah positif dan tidak signifikan, artinya bahwa terdapat pengaruh yang sangat rendah antara kinerja dengan penyelenggaran diklat. Jadi kesimpulannya adalah, (1) kinerja pegawai sudah sangat baik dengan nilai terendah berada pada indikator kehandalan dalam menyelesaikan tugas, (2) penyelenggaraan diklat sudah sangat baik dengan nilai terendah berada pada indicator kurikulum, serta (3) adanya pengarauh yang sangat rendah dari kinerja pegawai terhadap penyelenggaraan diklat. Saran dari penulis, yang pertama kehandalan pegawai dalam menyelesaikan tugas ditingkatkan dengan memberi pelatiahan dan izin belajar bagi para pegawainya; kedua penyusunan kurikulum diharapkan lebih disesuaikan lagi dengan peserta dengan mempelajari lebih dalam identitas peserta; ketiga diharapkan dilakukannya penelitian terhadap faktor-faktor lain yang mempengaruhi penyelenggaraan diklat, guna melihat tingkat pengaruhnya terhadap penyelenggaraan diklat.
\end{abstract}

Kata Kunci: kinerja, penyelenggaraan diklat.

Herdiansyah A.P, 2016, Pengaruh Kinerja Pegawai Terhadap Penyelenggaraan DIKLAT di Pusat Pelatihan Manajemen dan Kepemimpinan Pertanian (PPMKP) Ciawi Bogor. Jurnal Governansi. 


\section{PENDAHULUAN}

Setiap organisasi atau instansi dalam melaksanakan programnya selalu berusaha untuk mencapai tujuan. Salah satu faktor yang menjadi kriteria untuk melihat kelancaran tujuan suatu organisasi atau instansi adalah dengan mengidentifikasi dan mengukur kinerja pegawainya. Demikian halnya dengan aparat pemerintah sebagai pemberi layanan, mereka dituntut untuk dapat memberikan pelayanan yang terbaik, karena hal tersebut merupakan salah satu fungsi yang harus dijalankan oleh pemerintah. Tercapainya tujuan organisasi sangat ditentukan dari kinerja dan keefektifan para pegawai dalam menjalankan tugas. Setiap organisasi pada umumnya mengharapkan para pegawainya mampu melaksanakan tugasnya dengan efektif, efisien, produktif dan profesional. Semua ini bertujuan agar organisasi memiliki sumber daya manusia yang berkualitas dan sekaligus memiliki daya saing yang tinggi, sehingga nantinya akan menghasilkan kualitas pelayanan masyarakat yang sesuai dengan harapan masyarakat.

Kinerja seseorang merupakan kombinasi dari kemampuan, usaha, dan kesempatan yang dapat dinilai dari hasil kerjanya, (Sulistiyani, 2003). Kinerja pegawai mempengaruhi seberapa banyak mereka memberikan kontribusi kepada organisasi. Sebagai unsur organisasi, manusia memiliki peran yang sangat penting dalam menjalankan fungsinya dalam rangka kemajuan organisasi.Potensi setiap individu yang ada dalam organisasi harus dapat dimanfaatkan sebaik-baiknya sehingga mampu memberikan hasil yang maksimal. Di mana keberhasilan organisasi sangat tergantung pada peran manusia didalamnya karena manusia sebagai sumber daya yang potensial dan merupakan sumber kekuatan untuk menggerakkan roda aktivitas organisasi.
Menurut Mitchell dalam Sedarmayanti (2001:51) menyatakan bahwa kinerja meliputi 5 aspek yaitu:

1. Kualitas pekerjaan (Quality of work), yang terdiri dari komponen mutu hasil pekerjaan dan sikap dalam bekerja.

2. Ketepatan waktu (Promptness), yang terdiri dari komponen tingkat kehadiran dan pemanfaatan waktu luang.

3. Inisiatif (Inisiative), yang terdiri dari komponen tingkat inisiatif dan tanggung jawab terhadap pekerjaan.

4. Kecakapan (Capability), yang terdiri dari komponen kehandalan dalam menyelesaikan tugas dan pengetahuan tentang pekerjaan.

5. Komunikasi (Comunication), yang terdiri dari komponen kejujuran dalam menyampaikan pendapat dan kerjasama dalam menyelesaikan pekerjaan.

Realitas menunjukkan bahwa kondisi pegawai masih jauh dari yang diharapkan, dimana kualitas pegawai negeri sipil di Indonesia selama ini masih belum memuaskan karena rendahnya produktivitas kerja.

Peningkatan kualitas pegawai menjadi sangat penting dan perlu dilakukan secara terencana, terarah, dan berkelanjutan dalam rangka meningkatkan kemampuan dan profesionalisme. Dalam meningkatkan dan mengembangkan kemampuan pegawai salahsatu cara yang bisa dilakukan adalah dengan memberikan pendidikan dan latihan (diklat). Pendidikan dan pelatihan menurut Heidjrachman dan Suad (1997: 77), adalah: Pendidikan ialah suatu kegiatan untuk meningkatkan pengetahuan umum seseorang termasuk didalamnya peningkatan penguasaan teori dan keterampilan memutuskan terhadap persoalan-persoalan yang menyangkut kegiatan mencapai tujuan, sedangkan latihan membantu pegawai dalam 
memahami suatu pengetahuan praktis dan penerapannya, guna meningkatkan keterampilan, kecakapan, dan sikap yang diperlukan oleh organisasi dalam usaha mencapai tujuannya. Dalam penyelenggaraan diklat, penyelenggara memiliki peranan yang sangat penting dalam memberikan kualitas penyelenggaraan diklat.

Menurut Wusanto (2004: 89) bahwa hal-hal yang mempengaruhi diklat dibedakan menjadi dua, yaitu perangkat lunak (software) dan perangkat keras (hardware). Perangkat lunak dalam proses pendidikan dan pelatihan ini mencakup kurikulum, organisasi pendidikan dan pelatihan, peraturan-peraturan, metode belajar mengajar dan tenaga pelajar atau pelatih itu sendiri, sedangkan perangkat keras yang juga besar pengaruhnya terhadap proses pendidikan dan latihan adalah fasilitas-fasilitas yang mencakup gedung, buku-buku referensi, alat bantu pendidikan, dan sebagainya. Pusat Pelatihan Manajemen dan Kepemimpinan Pertanian (PPMKP) sebagai salahsatu PUSDIKLAT , mempunyai tugas melaksanakan pengembangan teknik pelatihan manajemen, kepemimpinan dan multimedia pertanian, serta fungsional non Rumpun Ilmu Hayat Pertanian. Dilihat dari tugasnya, kinerja pegawai PPMKP memiliki peranan yang sangat penting karena menyangkut bagaimana melaksanakan pengembangan dan pelatihan. Namun dalam setiap kehidupan berorganisasi tidak lepas darai adanya permasalahan yang terjadi, baik permasalahan internal maupun eksternal.

PPMKP pun memiliki permasalahan di dalam kinerja pegawainya, adanya perbedaan karakter pegawai yang dipengaruhi oleh pengetahuan, keterampilan, sikap, kedisiplinan dan faktor lainnya. Keadaan tersebut menimbulkan perbedaan kemampuan para pegawai dalam hal melaksanakan tugasnya. Sehingga tingkat efektivitas kerja pegawai akan bervariasi., ditambah dalam hal kedisiplinan pegawai yang menyangkut kehadiran dan ketepatan waktu pekerjaan, produktivitas pegawai pun menjadi permasalahan di sana.

Oleh karena itu untuk mengatahui seberapa besar pengaruh kinerja pegawai terhadap penyelenggaraan diklat di PPMKK, penelitian ini memiliki tujuan sebagai berikut: 1) Untuk mengetahui bagaimana kinerja pegawai Pusat Pelatihan Manajemen dan Kepemimpinan Pertanian (PPMKP) Ciawi Bogor. 2) Untuk mengetahui bagaimana penyelenggaraan diklat yang dilaksanakan oleh Pusat Pelatihan Manajemen dan Kepemimpinan Pertanian (PPMKP) Ciawi Bogor. 3) Untuk menguji ada tidaknya pengaruh kinerja pegawai terhadap penyelenggaraan diklat di Pusat Pelatihan Manajemen dan Kepemimpinan Pertanian (PPMKP) Ciawi Bogor.

Gambar 1. Pengaruh kinerja pegawai terhadap pnyelenggaraan diklat di PPMKP

\begin{tabular}{|l|}
\hline \multicolumn{1}{|c|}{ Kariabel X } \\
\hline - Kualitas pekerjaan (Quality of \\
\\
work) \\
- Ketepatan waktu (Promptness) \\
- Inisiatif (Inisiative) \\
- Kecakapan (Capability) \\
\end{tabular}

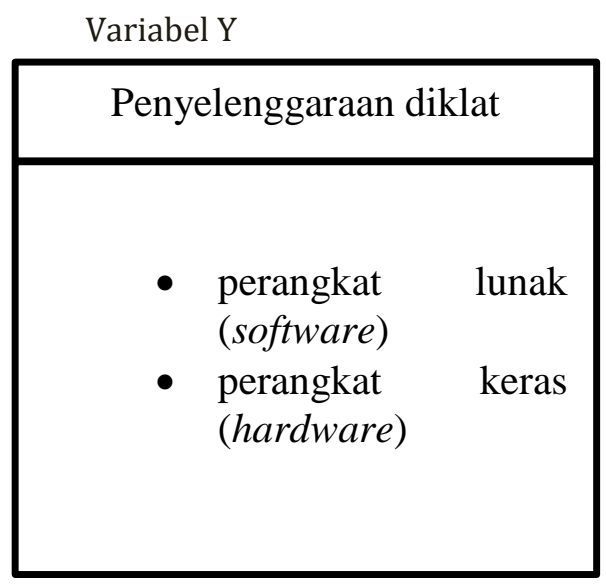




\section{MATERI DAN METODE}

Penelitian yang digunakan adalah penelitian kuantitatif dengan metode asosiatif dan deskriptif, metode asosiatif menurut Sugiyono (2007:11) adalah : "Penelitian asosiatif merupakan penelitian yang bertujuan untuk mengetahui hubungan antara dua variabel atau lebih. Dengan penelitian ini akan ditarik suatu kesimpulan teori yang dapat bertfungsi untuk menjelaskan dan mengontrol suatu gejala.. Menurut Sugiyono (2009: 14), Menurut Sugiyono (2007: 11) yang dimaksud penelitian Deskriptif adalah : "Penelitian yang dilakukan untuk mengetahui nilai variabel mandiri, baik sutu variabel atau lebih (independen) tanpa membuat perbandingan atau menghubungkan antara variabel satu dengan variabel lain."

\section{Populasi dan Sampel}

Penelitian dilakukan di Pusat Pelatihan Manajemen dan Kepemimpinan Pertanian (PPMKP) Ciawi Bogor, Populasi menurut Sugiyono (2008:117) adalah wilayah generalisasi yang terdiri atas obyek atau subyek yang mempunyai kualitas dan karakteristik tertentu yang ditetapkan oleh peneliti untuk dipelajari dan kemudian ditarik kesimpulannya.

Sampel adalah bagian dari populasi yang karakteristiknya hendak diselidiki dan dianggap bisa mewakili keseluruhan populasi (jumlahnya lebih sedikit dibandingkan jumllah populasinya)

Populasi di Pusat Pelatihan Manajemen dan Kepemimpinan Pertanian (PPMKP) Ciawi Bogor berjumlah 198 orang. Penarikan sampel dilakukan dengan menggunakan teknik Purposive sampling. sampling purposive adalah teknik penentuan sampel dengan pertimbangan tertentu. Rumus yang digunakan untuk menghitung besaran sampel yang diperlukan dalam penelitian ini adalah menggunakan rumus Yamane, yaitu:

$$
n=\frac{N}{N\left(d^{2}\right)+1}
$$

dengan tingkat kepercayaan (sampling error) 10\%, jumlah sampel penelitian sebanyak 68 pegawai.

Karakteristik responden berdasarkan jenis kelamin, usia, pendidikan dan bagian/bidang pekerjaan. Sebagaimana Tabel berikut ini.

Tabel

Jumlah dan Presentase Pegawai PPMKP Berdasarkan Karakteristik Responden

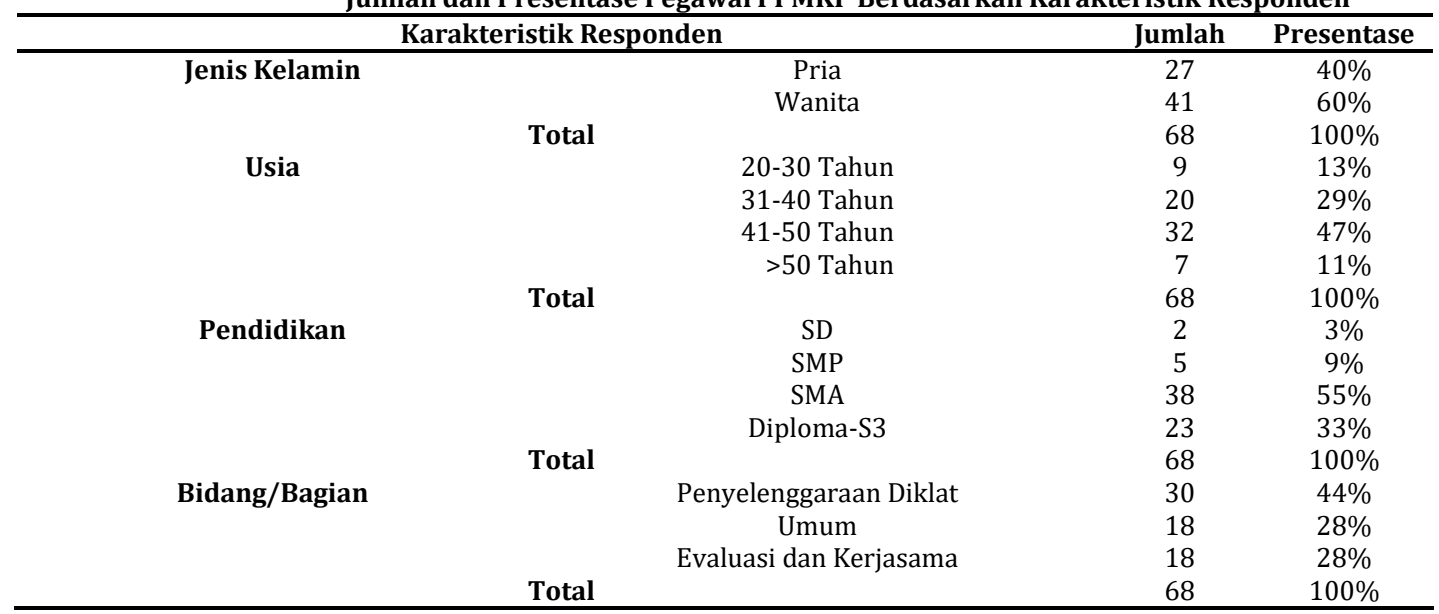

Hasil Penelitian :2016

Jenis dan Teknik Pengumpulan Data.

Dalam melaksanakan penelitian tentunya ada beberapa tahap-tahap yang 
harus dilakukan dan dilalui untuk mendapatkan data yang lengkap dengan menggali informasi, adalah sebagai berikut

1. Studi Kepustakaan

Teknik ini dilakukan dengan

mempelajari berbagai literatur yang berkaitan dengan Efektifitas Kinerja.

2. Studi Lapangan

Yaitu dengan meninjau secara

langsung ketempat lokasi penelitian, penulis melakukan ini untuk mendapatkan data dan informasi yang berhubungan dengan permasalahan yang dibahas dalam penelitian ini dengan cara :

a. Observasi, observasi adalah teknik memperoleh data dengan cara meneliti dan mengamati secara langsung pada sumber data yang akan dianalisis mengenai Kinerja pegawai dan penyelenggaraan diklat di PPMKP Ciawi Bogor yang akan diteliti.

b. Wawancara adalah proses tanya jawab secara lisan (Narbuko dan Achmadi, 1997 : 70). Wawancara dilakukan dengan pimpinan dan pegawai.

c. Angket merupakan teknik pengumpulan data yang dilakukan dengan cara memberi seperangkat pertanyaan atau pernyataan tertulis kepada responden untuk dijawabnya. Menurut Sugiyono (2008:135), skala Likert adalah yang mempunyai gradasi yang sangat positif sampai sangat negatif dan digunakan untuk mengukur sikap, pendapat, serta persepsi seseorang atau sekelompok orang tentang fenomena sosial juga untuk menganalisis kuantitatif dengan menggunakan skor untuk pertanyaan-pertanyaan tersebut dengan klasifikasi penilaian sebagai berikut:

\section{Tabel}

Klasifikasi Jawaban Skala Likert

\begin{tabular}{ccc}
\hline Jawaban & Klasifikasi & Nilai \\
A & Sangat Baik & $\mathbf{5}$ \\
B & Baik & 4 \\
C & Sedang & 3 \\
D & Buruk & 2 \\
E & Sangat Buruk & 1 \\
\hline
\end{tabular}

Diharapkan dalam penelitian ini diperoleh data yang seakurat mungkin guna pemaparan hasil penelitian secara lengkap dan jelas. Dan mengungkap apa yang ada pada realitanya.

\section{Pengolahan dan Analisis Data}

Dalam penelitian kuantitatif analisis data merupakan kegiatan setelah data dari seluruh responden atau sumber data lain terkumpul. Kegiatan dalam analisa data adalah mengelompokan data berdasarkan variabel dan jenis responden, mentabulasi data berdasarkan variabel dari seluruh responden, menyajikan data tiap variabel yang diteliti, melakukan perhitungan untuk menjawab rumusan masalah.

Teknik analisa data dalam penelitian ini menggunakan statistik deskriptif yaitu mendeskriptifkan Kinerja Pegawai PPMKP Ciawi Bogor. Statistik deskriptif digunakan untuk menganalisa data dengan cara mendeskripsikan atau menggambarkan data yang telah terkumpul sebagaimana adanya tanpa bermaksud membuat kesimpulan yang berlaku untuk umum atau generalisasi.

Untuk mempermudah analisis data dan penarikan kesimpulan maka disamping menggunakan perhitungan persentase juga dilakukan dengan menggunakan statistik deskriptif yaitu dengan menggunakan tabel frekuensi dan menggunakan perhitungan rata-rata (mean). Cara ini biasanya dengan menggunakan perhitungan Weight Mean Score (WMS) yaitu dilakukan pembobotan untuk setiap jawaban pilihan. Dengan pemberian skor tersebut, maka akan diperoleh variasi jawaban yang bergerak 1- 
5, karena itu interval antara satu kriteria dengan kriteria lainnya yang diperoleh angka sebesar 0,8. Angka ini diperoleh setelah adanya pengurangan dari nilai tertinggi dikurangi nilai terendah dan dibagi banyaknya alternatif jawaban. Sehingga diperoleh hasil sebagai berikut:

Tabel

Kriteria Penafsiran

\begin{tabular}{ll}
\hline Skor & Kriteria \\
$4,24-5,00$ & Sangat Baik \\
$3,43-4,23$ & Baik \\
$2,62-3,42$ & Sedang \\
$1,81-2,61$ & Buruk \\
$1,00-1,80$ & Sangat Buruk \\
\hline
\end{tabular}

Menurut Bakri Siregar $(1981 ; 20)$ data yang diperoleh dari lapangan lalu diolah berdasarkan jawaban responden melalui angket yang menggunakan rumus WMS:

\section{Gambar Rumus Weight Mean Score (WMS)}

$$
M=\frac{\sum(\mathrm{fx})}{\mathrm{n}}
$$

Keterangan:

$\mathrm{M} \quad=$ Perolehan angka kriteria penafsiran

$$
\begin{array}{ll}
\mathrm{f} & =\text { Frekuensi jawaban } \\
\mathrm{x} & =\text { Pembobotan (skala nilai) } \\
\sum & =\text { Penjumlahan } \\
\mathrm{n} & =\text { Jumlah seluruh jawaban } \\
\text { responden }
\end{array}
$$

Kemudian setelah langkah pertama selesai dilakukan, maka selanjutnya dibuat tabel sebagai berikut :

\section{Tabel Frekuensi}

\begin{tabular}{llcccc} 
No & $\begin{array}{c}\text { Alternatif } \\
\text { jawaban }\end{array}$ & $\mathbf{f}$ & $\mathbf{X}(\mathbf{x})$ & $\frac{\sum \boldsymbol{f}(\boldsymbol{x})}{\boldsymbol{n}}$ \\
\hline $\mathbf{1}$ & Sangat Baik & $\mathbf{5}$ & \\
$\mathbf{2}$ & Baik & $\mathbf{4}$ & \\
$\mathbf{3}$ & Sedang & $\mathbf{3}$ & \\
$\mathbf{4}$ & Buruk & $\mathbf{2}$ & \\
$\mathbf{5}$ & Sangat Buruk & $\mathbf{1}$ & \\
& Jumlah & &
\end{tabular}

Sumber : Bakri Siregar (1981 : 20)

Untuk menguji signifakansi hipotesis asosiatif dan bila masing-masing variabel yang dihubungkan berentuk data ordinal, diuji dengan menggunakan rumus korelasi Rank Spearman adalah sebagai berikut:

$$
\rho=1-\frac{6 \sum d i^{2}}{n\left(n^{2}-1\right)}
$$

Gambar : Rumus Korelasi Rank Spearman.

$\boldsymbol{\rho}$ :nilai korelasi rank spearman $\mathrm{d}$ : jumlah kuadrat selisih ranking variabel $x$ dan y atau $\mathrm{RX}-\mathrm{RY}$

$\mathrm{n}$ : Jumlah Sampel

Uji signifikansi dilakukan dengan menggunakan fasilitas aplikasi SPSS versi 16.00. Setelah melewati tahap perhitungan, maka untuk menegatahui tingkat hubungan antara variabel $x$ dengan variabel $y$ digunakan pedoman interpretasi korelasi menurut pendapat sugiyono.

Tabel

\section{Pedoman untuk memberikan} Interpretasi Koefisen Korelasi Interval Tingkat

Koefisien hubungan

$\begin{array}{cc}0,00-0,199 & \text { Sangat rendah } \\ 0,20-0,399 & \text { Rendah } \\ 0,40-0,599 & \text { Sedang } \\ 0,60-0,799 & \text { Kuat } \\ 0,80-1,0000 & \text { Sangat Kuat }\end{array}$

Sumber : Sugiyono 2012: 214 
Untuk mengetahui signifikansi perhitungan korelasi, maka hasil korelasi Rank Spearman perlu digunakan uji $\mathrm{t}$ menggunakan rumus statistik:

Gambar: Rumus T Hitung

$$
t=\frac{r s \sqrt{n-2}}{1-r s^{2}}
$$

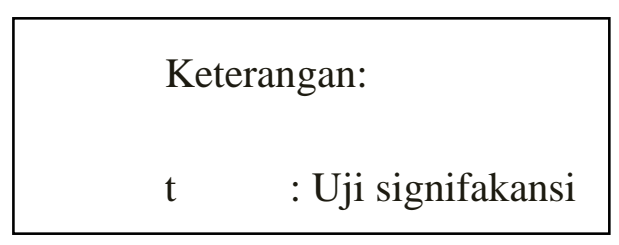

Melakukan uji hipotesis dari penelitian dalam hal ini dilakukan pengujian statistik terhadap Ho, yaitu : $r s=0$, Hi : $r s \neq 0$, dimana kriteria untuk menerima atau menolak hipotesis yang diajukan adalah jika :

- Jika $t_{\text {hitung }}<t_{\text {tabel, }}$ maka Hipotesis nol (Ho) diterima dan Hipotesis alternatif (Ha) ditolak, yang artinya Ho : $r s=0$ (tidak ada pengaruh antara kinerja pegawai terhadap penyelenggaraan diklat).

- Jika $t_{\text {hitung }}>t_{\text {tabel, }}$ maka Hipotesis nol (Ho) ditolak dan Hipotesis alternatif (Ha) diterima, yang artinya $\mathrm{Ha}: \mathrm{rs} \neq$ 0 (adanya pengaruh antara kinerja pegawai terhadap penyelenggaraan diklat).

Selain itu untuk mengetahui sejauh mana variabel $\mathrm{x}$ memberikan kontribusinya terhadap variabel y dalam penelitian ini, maka digunakan perhitungan koefisien determinasi $(\mathrm{Kd})$, yaitu:

$$
\mathrm{Kd}=\rho^{2} \mathrm{X} 100 \%
$$

Gambar : Koefisen Determinasi

Keterangan:

$\mathrm{Kd} \quad=$ Koefisien determinasi

$\rho \quad=$ Koefisen korelasi

sumber sugiyono (2012:177)

\section{HASIL DAN PEMBAHASAN}

Berdasarkan hasil penelitian, diperoleh bahwa kinerja pegawai PPMKP memperoleh hasil akhir sebesar 4,37 dapat dikategorikan "sangat baik". Dengan kata lain pegawai PPMKP melaksanakan pekerjaannya dengan sangat baik. Berikut rekapitulasi variabel kinerja pegawai.

\section{Tabel}

\begin{tabular}{|c|c|c|c|c|}
\hline $\begin{array}{c}\text { Variab } \\
\text { el }\end{array}$ & Dimensi & Indikator & M & $\begin{array}{l}\text { Kriteria } \\
\text { penilaian }\end{array}$ \\
\hline \multirow{12}{*}{ Kinerja } & \multirow{2}{*}{$\begin{array}{c}\text { Kualitas } \\
\text { pekerjaan } \\
\text { (Quality of } \\
\text { work) }\end{array}$} & Hasil pekerjaan & 4,58 & Sangat Baik \\
\hline & & $\begin{array}{l}\text { Sikap dalam } \\
\text { bekerja }\end{array}$ & 4,51 & Sangat Baik \\
\hline & \multirow{3}{*}{$\begin{array}{l}\text { Ketepatan } \\
\text { waktu } \\
\text { (Promptness) }\end{array}$} & Tingkat kehadiran & 4,57 & Sangat Baik \\
\hline & & $\begin{array}{l}\text { Pemanfaatan } \\
\text { waktu luang }\end{array}$ & 4,19 & Baik \\
\hline & & Tingkat inisiatif & 4,23 & Baik \\
\hline & $\begin{array}{c}\text { Inisiatif } \\
\text { (Inisiative) }\end{array}$ & $\begin{array}{l}\text { Tanggung jawab } \\
\text { terhadap } \\
\text { pekerjaan }\end{array}$ & 4,50 & Sangat Baik \\
\hline & \multirow{2}{*}{$\begin{array}{l}\text { Kecakapan } \\
\text { (Capability) }\end{array}$} & $\begin{array}{l}\text { Kehandalan dalam } \\
\text { menyelesaikan } \\
\text { tugas }\end{array}$ & 4,08 & Baik \\
\hline & & $\begin{array}{l}\text { Pengetahuan } \\
\text { tentang pekerjaan }\end{array}$ & 4,42 & Sangat Baik \\
\hline & \multirow{2}{*}{$\begin{array}{c}\text { Komunikasi } \\
\text { (Comunicatio } \\
n \text { ) }\end{array}$} & $\begin{array}{l}\text { Kejujuran dalam } \\
\text { menyampaikan } \\
\text { pendapat }\end{array}$ & 4,36 & Sangat Baik \\
\hline & & $\begin{array}{l}\text { Kerjasama dalam } \\
\text { menyelesaikan } \\
\text { pekerjaan. }\end{array}$ & 4,29 & Sangat Baik \\
\hline & Jumlah & 10 & 43,73 & \\
\hline & \multicolumn{2}{|c|}{$M=\frac{\sum S k o r}{\text { Jumlah Indikator }}$} & 4,37 & Sangat Baik \\
\hline
\end{tabular}

\section{Rekapitulasi variabel kinerja}

Sumber: Penelitian 2016

Berdasarkan hasil penelitian, bahwa penyelenggaraaan diklat di PPMKP memperoleh hasil akhir sebesar 4,39 dapat dikategorikan "sangat baik". Berikut rekapitulasi variabel penyelenggaraan diklat. 


\section{Tabel}

\section{Rekapitulasi variabel penyelenggaraan} diklat

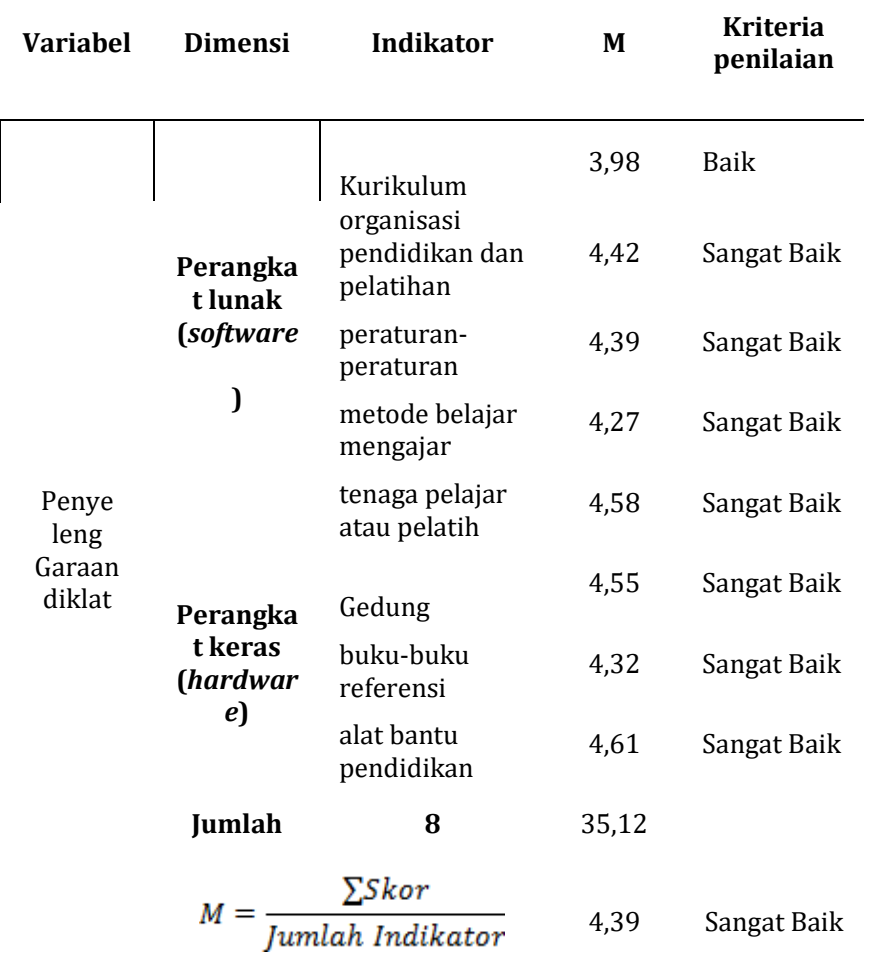

Sumber: Penelitian 2016

\section{Uji Hipotesis}

Uji hipotesis ini untuk mengetahui pengaruh kinerja pegawai terhadap penyelenggaraan diklat di PPMKP berdasarkan uji korelasi rank spearman, yang dapat dilihat pada tabel 5 .

Tabel

Hasil Uji Signifikansi dengan SPSS 16.00

\begin{tabular}{|c|c|c|c|c|}
\hline & & & $\begin{array}{c}\text { Kiner } \\
\text { ja }\end{array}$ & $\begin{array}{c}\text { Penyele } \\
\text { nggaraa } \\
\mathrm{n} \text { diklat }\end{array}$ \\
\hline $\mathrm{S}$ & \multirow{4}{*}{ Kinerja } & Koefisien & \multirow{2}{*}{1,000} & \multirow{2}{*}{,037 } \\
\hline $\mathrm{p}$ & & Korelasi & & \\
\hline $\mathrm{e}$ & & Sig. (2-arah) & . & ,766 \\
\hline ar & & $\mathrm{N}$ & 68 & 68 \\
\hline $\begin{array}{c}\mathrm{m} \\
\mathrm{a}\end{array}$ & \multirow{3}{*}{$\begin{array}{c}\text { Penyeleng } \\
\text { garaan } \\
\text { diklat }\end{array}$} & $\begin{array}{c}\text { Koefisien } \\
\text { Korelasi }\end{array}$ & ,037 & 1,000 \\
\hline $\begin{array}{l}\mathrm{n}^{\prime} \\
\mathrm{s}\end{array}$ & & Sig. (2-arah) & ,766 & \\
\hline $\mathrm{rh}$ & & $\mathrm{N}$ & \multirow[t]{2}{*}{68} & \multirow[t]{2}{*}{68} \\
\hline Sun & Penelitian & & & \\
\hline
\end{tabular}

Berdasarkan tabel 5 dapat disimpulkan bahwa nilai korelasi antara variabel kinerja dengan variabel penyelenggaraan diklat sebesar 0,037 dengan tingkat hubungan sangat rendah, dan nilai signifikansi sebesar 0,766 yang artinya tidak signifikan, karena nilai tersebut lebih besar dari taraf kesalahan 0,05 . Berdasarkan kriteria Interpretasi Koefisien Korelasi tabel 3.4, besaran koefisien 0,037 mengindikasikan tingkat hubungan yang sangat rendah.

\section{Uji Signifikansi}

Dari hasil perhitungan diperoleh nilai $t_{\text {hitung }}$ hasil penelitian sebesar 0,302 kemudian nilai thitung dibandingkan dengan $t_{\text {tabel }}$ distribusi $t$ dengan $\mathrm{dk}$ (derajat kebebasan) 68-2= 66 dan taraf signifikan $5 \%$ maka diperoleh nilai tabel adalah 1,668. Hal tersebut menunjukan bahwa ternyata $\mathrm{T}_{\text {hitung }}<\mathrm{T}_{\text {tabel }}$. Dengan demikian maka dapat disimpulkan bahwa koefisien korelasi rank spearman tidak signifikan, sehingga Ho diterima dan Ha ditolak.

Untuk mengetahui sejauh mana variabel Kepemimpinan $(\mathrm{X})$ memberikan pengaruhnya terhadap variabel Partisipasi Masyarakat (Y) dalam penelitian ini, maka digunakan perhitungan koefisien determinasi (Kd), yaitu:

$$
\begin{aligned}
\mathrm{Kd} & =0.037^{2} \times 100 \% \\
& =0,14 \%
\end{aligned}
$$

Dari perhitugan koefisien determinansi tersebut dapat ditafsirkan bahwa variabel kinerja mempengaruhi variabel penyelenggaraan diklat sebesar $0,14 \%$, sisanya dipengaruhi variabel atau faktor lain.

\section{KESIMPULAN DAN SARAN}

\section{Kesimpulan}

1. Kinerja yang dilakukan oleh pegawai PPMKP sudah sangat baik, hal ini dapat dilihat dari tabel 4.18, skor akhir untuk variabel kinerja adalah 4,37. Hal ini tidak terlepas dari para pegawai yang mampu menyelesaikan pekerjaan dengan 
kualitas yang baik, sikap profesionalisme yang didukung oleh tingkat kedisiplinan pegawai, salah satunya adalah kehadiran yang cukup tinggi. Juga pemberian diklat yang berguna untuk menambah kehandalan dan pengetahuan akan pekerajaan, inisiatif dan tanggung jawab setiap individu maupun kelompok, ditambah baiknya komunikasi secara vertical maupun horizontal.

2. Dilihat dari tabel 4.29 Penyelenggaraan diklat di PPMKP memperoleh skor akhir 4,39 yang berada pada kategori sangat baik. Hal tersebut menyatakan bahwa penyelenggaraan diklat di PPMKP sudah sangat baik dengan didukung oleh sarana dan prasarana yang memadai serta tenaga-tenaga ahli yang kompeten dalm mempersiapkan diklat.

3. Korelasi kinerja dengan penyelenggaraan diklat diperoleh nilai sebesar 0,037 mengindikasikan tingkat hubungan yang sangat rendah. Dan nilai signifikansi sebesar 0,766 yang artinya tidak signifikan, karena besaran koefisien nilai signifikansi yaitu 0,766 lebih besar dibandingkan dengan taraf kesalahan. Lalu dengan menggunakan rumus koefisien determinansi, pengaruh kinerja pegawai terhadap penyelenggaraan diklat mendapat nilai sebesar $0,14 \%$, yang artinya pengaruh kinerja pegawai PPMKP dapat dikatakan sangat kecil pengaruhnya terhadap penyelenggaraan diklat, sisanya dipengaruhi oleh variabel atau faktor lain.

\section{Saran}

1. Dari variabel kinerja, kehandalan dalam menyelesaikan pekerjaan menjadi indikator dengan nilai terendah dengan 4,08. Diharapkan mampu ditingkatkan, tidak hanya dengan memberi pendiikan dan pelatihan terhadap pegawai saja, tapi juga memberi ijin belajar sehingga pegawai mampu menyelesaikan pekerjaan dengan lebih baik lagi.
2. Penyusunan kurikulum diharapkan lebih disesuaikan lagi dengan peserta dengan mempelajari lebih dalam identitas peserta, sehingga penyelenggaraan diklat dapat berjalan semaksimal mungkin.

3. Diharapkan dilakukannya penelitian terhadap faktor-faktor lain yang mempengaruhi kinerja, guna melihat tingkat pengaruhnya terhadap penyelenggaraan diklat.

\section{DAFTAR PUSTAKA}

Abdurrahman Fatoni. (2006). Manajemen Sumber Daya Manusia. Jakarta: Rineka Cipta.

Ambar T Sulistiyani \& Rosidah. (2009). Manajemen Sumber Daya Manusia: Konsep, Teori, dan Pengembangan dalam Konteks Organisasi Publik. Yogyakarta: Graha Ilmu.

Anwar Prabu Mangkunegara. (2004). Manajemen Sumber daya manusia Perusahaan. Bandung: PT Remaja Rosda karya.

Anwar Prabu Mangkunegara. (2010). Evaluasi Kinerja SDM. Bandung: PT Refika Aditama.

Guritno, Bambang dan Waridin. (2005). Pengaruh Persepsi Karyawan Mengenai Perilaku Kepemimpinan, Kepuasan Kerja Dan Motivasi Terhadap Kinerja. JRBI. Vol 1. No 1. Hal: 63-74.

Mahmudi. (2015). Manajemen Kinerja Sektor Publik, Yogyakarta: UPP STIM YKPN.

Moh As'ad. (2003). Psikologi Industri. Yogyakarta: Libery.

Sulistiyani, Ambar T. dan Rosidah. (2003). Manajemen Sumber Daya Manusia. Yogyakarta: Graha Ilmu

Moh. Pabundu Tika. (2010). Budaya Organisasi dan Peningkatan Kinerja Perusahaan. Jakarta: PT Bumi Aksara. 
Mohamad Mahsun. (2006). Pengukuran Kinerja Sektor Publik. Yogyakarta: BPFE Yogyakarta.

Rivai, Veithzal dan Basri. (2005). Performance Appraisal: Sistem Yang Tepat Untuk Menilai Kinerja Karyawan Dan Meningkatkan Daya Saing Perusahaan. Jakarta: Rajagrafindo Persada.

Sedarmayanti. (2009). Sumber Daya Manusia dan Produktivitas Kerja. Bandung: Mandar Maju.

Simamora, Henry, 1997. Manajemen Sumber Daya Manusia. Edisi Kedua.STIE : YKPN

Sjafri Mangkuprawira. (2011). Manajemen Sumber Daya Manusia Strategik. Jakarta: Ghalia Indonesia

Soekidjo Notoatmodjo. (2003). Pengembangan Sumber Daya Manusia. Jakarta: PT. Ranika Cipta.

Sugiyono. (2011). Metode Penelitian Kuantitatif Kualitatif dan $R \& D$, Bandung: CV Alfabeta.

Sugiyono. (2012). Metode Penelitian Administrasi, Bandung: CV Alfabeta.

Suharsimi Arikunto. (2006). Prosedur Penelitian. Jakarta: PT. Rineka Cipta

Susilo Martoyo. (2004). Sumber Daya Manusia. Yogyakarta: BPFE.

Tika, P. (2006). Budaya Organisasi Dan Peningkatan Kinerja Perusahaan. Jakarta: PT Bumi Aksara.

Wursanto. (1989). Manajemen Kepegawaian 1. Yogyakarta: Kanisius.

www.ppmkp.bppsdmp.deptan.go.id 